\title{
Bem Barbiezinha.... Fascista: ironia em post
}

DOI: http://dx.doi.org/10.21165/el.v49i2.2722

\section{Laura Pereira Teixeira'}

\section{Resumo}

O presente trabalho propõe analisar a constituição irônica de uma imagem de mulher construída em enunciados veiculados pelas páginas intituladas "Barbie Fascista" e "Barbie e Ken Cidadãos de Bem", do Facebook. A fundamentação teórica se baseia nos estudos bakhtinianos, sobretudo nas concepções de diálogo, linguagem, sujeito, signo e ideologia. O método dialógico de análise se pauta no cotejo com outros enunciados, de diversas esferas. O objetivo é refletir e compreender a construção enunciativa da ironia por inversão, utilizada como forma de questionamento e ridicularização de um tipo social de mulher considerada abastada e com um posicionamento político de direita, com tendências conservadoras. Os resultados se voltam à reflexão acerca das imagens de mulher construídas nessas páginas, além do papel e noção de mulher neste momento histórico. A contribuição desta proposta se volta a um estudo sobre quem é e o que é ser mulher no Brasil da era Bolsonaro.

Palavras-chave: Barbie Fascista; mulher; sujeito; ideologia; Círculo de Bakhtin.

1 Universidade Estadual Paulista "Júlio de Mesquita Filho" (UNESP), Araraquara, São Paulo, Brasil; laura.pteixeira@outlook.com; https://orcid.org/0000-0001-9464-7849 


\title{
Like a Barbie girl... but fascist: irony in posts
}

\begin{abstract}
The present work proposes to analyze the ironic constitution of an image of woman constructed on statements of the pages named "Barbie Fascista" and "Barbie e Ken Cidadãos de Bem", from Facebook. The theoretical foundation is based on the bakhtinian studies, mostly about the conceptions of dialogue, language, subject, sign and ideology. The dialogical method of analysis is based on the collation with other statements, from many spheres. The aim is to reflect and understand the enunciative construction of irony by inversion, used as a form of questioning and ridicularization of a social type of woman considered rich e with a right political position, with conservative tendencies. The results turn to the reflection about the images of woman constructed on those pages, further the role and notion of woman on this historic moment. The contribution of this proposal is to think about who is and what it is to be a woman in the Brazil of Bolsonaro's era.
\end{abstract}

Keywords: Fascist Barbie; woman; subject; ideology; Bakhtin's Circle.

\section{Da vida para o Face: os memes da Barbie Fascista}

O presente trabalho, apresentado no Simpósio Proposto intitulado "Mulher em discurso e discurso de mulher", durante a $67^{a}$ edição do Seminário do GEL, propõe analisar enunciados selecionados a partir das páginas Barbie Fascista ${ }^{2}$ e Barbie e Ken Cidadãos de $\mathrm{Bem}^{3}$, do Facebook. As páginas mencionadas veiculam enunciados memes de caráter irônico, em referência à situação política do Brasil no período da eleição presidencial em 2018, assim como ao governo de Jair Bolsonaro posteriormente. Os enunciados-meme expõem os posicionamentos dos eleitores/apoiadores bolsonaristas e os escândalos relacionados ao governo de maneira cômica, ao utilizar a ironia como principal recurso. Observando o expressivo número de curtidas e compartilhamentos das postagens dessas páginas pelos usuários da rede social, propomos refletir acerca da imagem de mulher que é veiculada por meio desses memes, em um retrato que demonstra o embate entre vozes sociais, posicionamentos políticos, ideologias e axiologias.

Os memes da Barbie Fascista surgiram durante o segundo turno das eleições de 2018, disputado pelos candidatos Fernando Haddad, do Partido dos Trabalhadores (PT), e Jair Bolsonaro, do Partido Social Liberal (PSL). Em consonância com os movimentos Ele Não e Mulheres unidas contra Bolsonaro, os memes nesse momento elencavam as declarações polêmicas do então candidato de uma forma irônica. Além disso, os eleitores/apoiadores

2 Disponível em: https://www.facebook.com/barbiefascista/. Acesso em: 14 set. 2019.

3 Disponível em: https://www.facebook.com/barbieekencidadaosdebem/. Acesso em: 14 set. 2019. 
bolsonaristas são representados como as personagens Barbie, Ken e seus amigos, em uma crítica feita pelos enunciadores das páginas ao deslocamento social, alienação e desconhecimento político desses cidadãos.

Assim, pensando nesses enunciados não de forma isolada, mas inseridos em um contexto histórico, político e social, filiamo-nos às concepções teóricas da filosofia da linguagem do Círculo de Bakhtin, de forma a refletirmos sobre o diálogo estabelecido entre os memes que constituem nosso corpus de análise e as reportagens veiculadas na rede sobre o governo, além dos valores sociais veiculados pelos apoiadores bolsonaristas e aqueles que se manifestam em repúdio. Outrossim, pensamos sobre os conceitos de signo ideológico, visto que entendemos a Barbie Fascista enquanto ressignificação da realidade, além dos postulados sobre ideologia, linguagem e sujeito, com o intuito de compreender a construção desses memes e sua relevância na sociedade brasileira contemporânea. Para tanto, seguimos o método dialógico, que se pauta no cotejo com outros enunciados, por exemplo os da esfera jornalística, em um estabelecimento de comparação, para refletir sobre as possíveis aproximações, distanciamentos, concordâncias e refutações.

Ressaltamos que o presente trabalho foi suscitado a partir de nossa pesquisa de Mestrado acadêmico, ainda em andamento, intitulada "Bem Barbiezinha... Fascista: Análise bakhtiniana de vozes sociais sobre mulheres". A atualidade de nosso tema permite com que teçamos considerações sobre a maneira com que sujeitos se posicionam responsiva e responsavelmente nas redes sociais, enquanto forma de resistência social.

\section{Diálogo nos memes: reflexões acerca dos conceitos bakhtinianos}

"A palavra é o fenômeno ideológico par excellence" (VOLÓCHINOV, 2017, p. 98). A partir desse postulado, ressaltamos como as noções de linguagem, ideologia e signo ideológico estão intricadas de acordo com os estudos bakhtinianos. É por meio da palavra que os sujeitos conseguem se estabelecer perante o mundo, respondendo sobre ele e modificando-o responsiva e responsavelmente, em reflexo e refração, em embates ou consensos, enfim: a linguagem é uma característica humana por excelência, tal qual a ideologia.

Qualquer fenômeno ideológico é não apenas um reflexo, uma sombra da realidade, mas também uma parte material dessa mesma realidade. Qualquer fenômeno ideológico sígnico é dado em algum material: no som, na massa física, na cor, no movimento do corpo e assim por diante. [...] O signo é um fenômeno do mundo externo. Tanto ele mesmo, quanto todos os efeitos por ele produzidos, ou seja, aquelas reações, aqueles movimentos e aqueles novos signos que ele gera no meio social circundante, ocorrem na experiência externa. (VOLÓCHINOV, 2017, p. 94). 
Um signo ideológico surge no processo de interação social, entre os sujeitos que vivem em determinado contexto e o ressignificam, simbolizam de diferentes formas a realidade, com as valorações daquele período, daquele horizonte social e do grupo ao qual pertencem. É o que ocorre, para citar como exemplo o material aqui utilizado para análise, com os memes da Barbie Fascista, que transformam os eleitores de Bolsonaro nas personagens Barbie, Ken e amigos, valorando-os enquanto sujeitos fúteis, despolitizados, em um embate entre classes sociais distintas que tentam, pelo discurso, imprimir na sociedade suas ideologias e axiologias. Entendemos, neste trabalho, a Barbie Fascista enquanto signo ideológico, pois imprime nos enunciados memes a valoração elencada por vozes sociais que se posicionam na internet contra o bolsonarismo.

Como sabemos, todo signo surge entre indivíduos socialmente organizados no processo de sua interação. Portanto, as formas do signo são condicionadas, antes de tudo, tanto pela organização social desses indivíduos quanto pelas condições mais próximas da sua interação. (VOLÓCHINOV, 2017, p. 109).

Posto isso, compreendemos que os sujeitos se valem da linguagem para se posicionar no mundo, expressando suas ideologias e axiologias por meio de signos, influenciados pelos valores e pelo contexto em que estão inseridos. De acordo com Volóchinov (2017 [1929], p. 91, grifo do autor), "tudo o que é ideológico possui uma significação: ele representa algo encontrado fora dele, ou seja, ele é um signo. Onde não há signo também não há ideologia".

O conceito de ideologia para o Círculo de Bakhtin não possui o caráter pejorativo que comumente atrela-se à palavra, com sentido de mascaramento da realidade, ou ainda de ideário. Por sua vez, a ideologia nos estudos bakhtinianos diz respeito às manifestações da superestrutura, como a religião, a ciência, a política, etc. Todos os enunciados que nos permeiam, que constituem todas as esferas de atividade humana, são ideológicos (FARACO, 2009). Dessa maneira, não existe um enunciado que seja neutro, visto que cada sujeito imprime em suas produções as suas axiologias, vivências, o contexto sóciohistórico em que está inserido, além de trazer em seu discurso o eco do discurso alheio o que faz com que não seja possível (nem interessante) pensar em um discurso fundador, primeiro.

Partimos do fato de que o "enunciado é pleno de tonalidades dialógicas" (BAKHTIN, 2011, p. 298), pois os discursos são permeados por discursos alheios, abrem espaço para réplicas, visto que a palavra é prenhe de resposta. Diálogo não necessariamente significa consenso, mas pode significar o embate entre vozes. Exemplifiquemos o que até aqui explanamos com o meme da página Barbie Fascista, publicado durante o segundo turno das eleições de 2018. 
Figura 1. Meme da Barbie Fascista pelo direito de me defender!!!!! pelo direito de me sentir segura dentro da minha própria casa!! somos cidadões de bem!! \#CHEGA \#PTNUNCAMAIS \#ELESIM \#B17

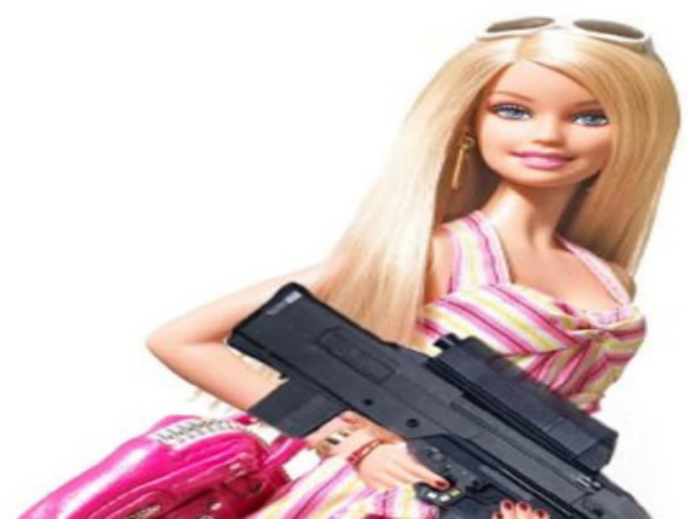

Fonte: Barbie Fascista, 2019, on-line (https://bit.ly/2UsTpRF)

O meme apresentado na Figura 1 explicita o diálogo, ou embate, travado entre dois grupos com diferentes inclinações políticas - entre bolsonaristas e os que se opõem ao bolsonarismo. A campanha eleitoral de Bolsonaro foi marcada pelo discurso de liberação das armas para civis. O meme aborda essa questão, que dividiu os eleitores, assim como outros temas, acentuando a polarização política do país. Os bolsonaristas, por meio de publicações em redes sociais e no aplicativo WhatsApp, afırmavam que se sentiriam mais seguros com o porte de armas. Esse discurso é retomado no meme de forma irônica, com uma Barbie segurando uma arma para ilustrar o discurso que está sendo ridicularizado pelos autores do meme (assim como por aqueles que o curtem e compartilham). As hashtags auxiliam na composição do enunciado, fazendo referência ao movimento \#EleNão, mas de maneira invertida, em um protesto dos bolsonaristas com a réplica \#EleSim.

A ironia, juntamente com o caráter cômico dos memes, ajuda na construção de uma crítica social feita nas redes pelos usuários. Por motivos cronológicos, sabemos que Bakhtin não estudou os memes ao se debruçar sobre a história do riso, mas podemos fazer uso de seu estudo sobre a obra de Rabelais e as festividades populares na Idade Média, com o intuito de compreender o riso como crítica social. As festas e cerimônias populares da Idade Média, por exemplo, o Carnaval e as paródias de festas religiosas provocavam, de acordo com Bakhtin (2010), um riso que abalava as oficialidades da época. Podemos refletir sobre os memes a partir das reflexões tecidas por Bakhtin ao passo que são enunciados que visam criticar tanto a candidatura quanto o governo de Jair Bolsonaro, bem como seus eleitores e apoiadores. Elaborados com ironia, com o uso 
das frases ditas pelos próprios bolsonaristas com fotos de bonecas Barbie que sorriem constantemente e vestem rosa, de forma a remeter à alienação, os memes provocam o riso dos internautas que também compactuam com a orientação política das páginas (anti-bolsonaristas), em uma maneira de posicionar-se contra a oficialidade que se impõe no Brasil com o novo governo.

O riso revelou de maneira nova o mundo, no seu aspecto mais alegre e mais lúcido. Seus privilégios exteriores estão indissoluvelmente ligados às suas formas interiores, constituem de alguma maneira o reconhecimento exterior desses direitos interiores. Por essa razão o riso, menos do que qualquer outra coisa, jamais poderia ser um instrumento de opressão e embrutecimento do povo. Ninguém conseguiu jamais torná-lo inteiramente oficial. Ele permaneceu sempre uma arma de liberação nas mãos do povo. (BAKHTIN, 2010, p. 81).

Dessa forma, podemos observar que o discurso não se limita, pelo contrário, fica em constante movimento, sendo modificado em diferentes tempos e espaços, por diferentes sujeitos, de distintos contextos. Assim, o processo dialógico é maleável, já que possibilita retomar discursos do passado e dialogar com discursos vindouros, possibilita ainda que diferentes vozes sociais se digladiem na arena que é o discurso. Os enunciadosmeme aqui tomados como objeto de pesquisa são singulares enquanto acontecimentos irrepetíveis, mas plurais enquanto elos na cadeia discursiva.

\section{A ironia dos memes enquanto crítica política}

A repercussão expressiva dos memes da Barbie Fascista ultrapassou o período eleitoral de 2018 e se estendeu para acompanhar o andamento do governo Bolsonaro. Os memes ${ }^{4}$ possuem a característica de deslocarem discursos oficiais, com tons sérios, por vezes polêmicos, transformando-os em enunciados cômicos, que podem divertir, desestabilizar, relativizar situações e sempre provocar a reflexão crítica.

Em um primeiro momento, quando temos contato com os memes das páginas analisadas, podemos pensar que o autor dos memes concorda com as declarações ali enunciadas. Contudo, a assinatura desses memes é contrária, ou seja, por meio de uma inversão, possibilitada pela ironia, encontramos um tom valorativo, marcado tanto no linguístico quanto no visual, que evidencia uma oposição aos pensamentos e posturas dos eleitores bolsonaristas. Ressaltamos que, por ironia, entendemos assim como postula Brait (2008, p. 73):

4 Publicação comum em redes sociais, com caráter cômico, e normalmente composto por elementos verbais e não-verbais de forma sucinta. Os memes fazem menção a algum acontecimento político, alguma notícia "viral", bem como a brincadeiras entre internautas. São muito compartilhados na rede, ganhando relevância entre os usuários principalmente por serem engraçados e/ou ácidos. 
[...] a ironia pode ser enfrentada como um discurso que, por meio de mecanismos dialógicos, se oferece basicamente como argumentação direta e indiretamente estruturada, como paradoxo argumentativo, como afrontamento de ideias e de normais institucionais, como instauração da polêmica ou mesmo como estratégia defensiva.

Os memes, tal qual as charges, tirinhas e quadrinhos em outros períodos históricos, possibilitam um dizer sobre a política que em outras esferas não seriam adequados, mas isso é possibilitado principalmente pelo uso do humor como ferramenta de resistência e de deslocamento do oficial.

Rica, loira e magra, a figura da boneca da Mattel, a Barbie, passa a circular pelas redes abordando questões políticas e sociais. De seu mundo privilegiado, Barbie comenta a situação política do Brasil de 2018 e, posteriormente, sobre o governo Bolsonaro. Por vezes ela aparece sozinha nas publicações, em outras está acompanhada por seu namorado, Ken, figura que exalta o padrão masculino heterossexual, branco e rico, ou com seus amigos. Nos memes podemos observar um processo que transforma os eleitores bolsonaristas em personagens, emitindo suas opiniões que demonstram falta de noção, desconhecimento acerca de temas políticos e sociais, além de um deslocamento social do lugar de fala dos mesmos. A ironia está contida sobretudo no fato de que esses posicionamentos costumam ser proferidos pelos apoiadores ou pelo próprio Bolsonaro.

Elegemos aqui alguns dos memes que, em um processo dialógico, estabelecem relação com discursos comumente propagados nas mídias e pelo senso comum. Assim, retomamos a matéria "Bela, recatada e do lar"5, veiculada pela Revista Veja, em 2016, às vésperas da concretização do impeachment de Dilma Rousseff. Ao estabelecer uma nítida oposição entre a ex-presidenta e Marcela Temer, a revista divulgou um padrão feminino a ser seguido, da mulher que apoia o marido, cuida dos afazeres domésticos e dos filhos, mas que também é bela, ou seja, vaidosa e, no caso de Marcela, jovem. O discurso da Veja causou repercussão e, desde então, observa-se que é retomado tanto por aqueles que concordam com ele, como os que o refutam. Em uma discussão semelhante, suscitada durante o segundo turno das eleições 2018, o discurso de que a mulher que é feminina não pode ser feminista, e vice-versa, circula pelas redes e suscita réplicas, como o meme abaixo.

5 Disponível em: https://veja.abril.com.br/brasil/marcela-temer-bela-recatada-e-do-lar/. Acesso em: 14 set. 2019. 
Figura 2. Feministas versus femininas
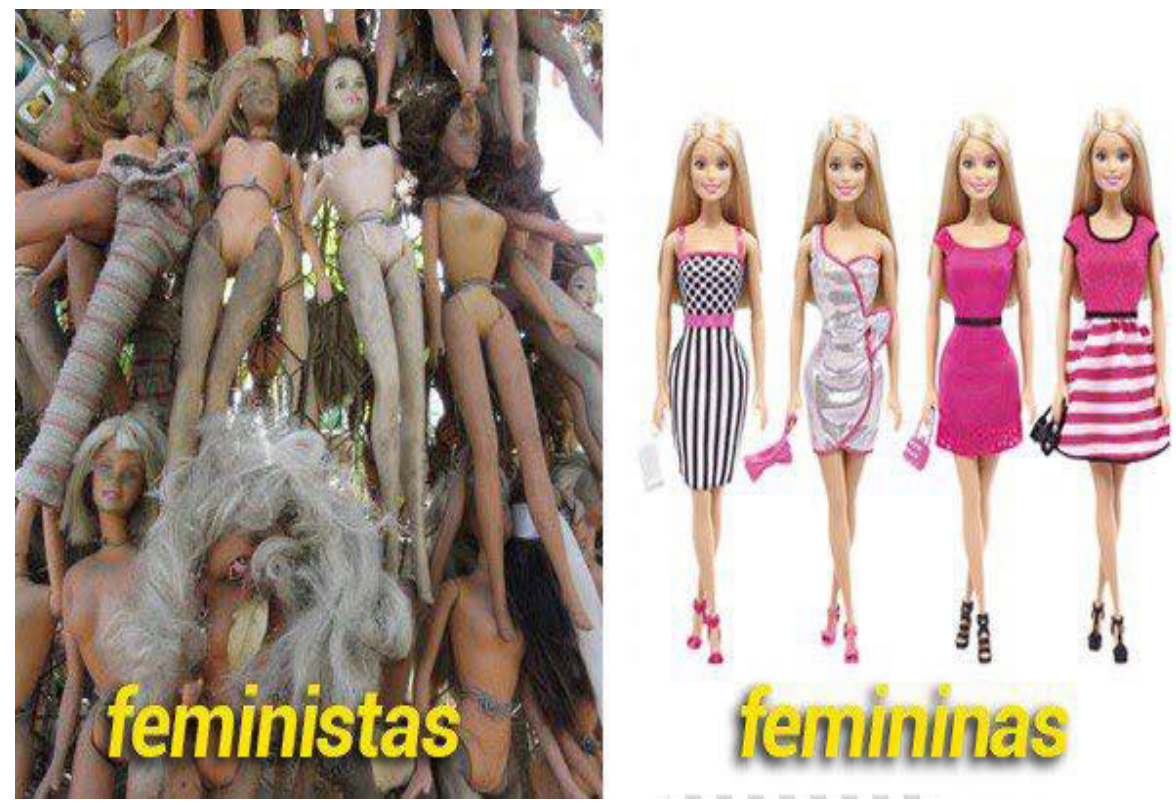

Fonte: Barbie e Ken Cidadãos de Bem, 2019, on-line (https://bit.ly/2XMNhWL)

Na figura 2, o pensamento de que é impossível ser feminina e feminista ao mesmo tempo fica explicitado, mas é abordado pelo meme de maneira irônica, em crítica aos que pensam dessa maneira e promovem esse tipo de pensamento preconceituoso, mas de maneira que provoca o riso, suavizando o conteúdo. À esquerda da figura podemos ver bonecas nuas, em alusão aos movimentos do feminismo radical, em que manifestantes costumam desnudar os seios como ato de protesto. As bonecas aparentam estar sujas, com os cabelos bagunçados, reforçando a ideia de que a mulher feminista não cuida de sua aparência. Já à direita vemos uma imagem oposta, com a disposição de quatro Barbies usando salto alto e acessórios, com cabelos alinhados, roupas em cor de rosa, demonstrando feminilidade, beleza e delicadeza, características que são inerentes às mulheres que não se envolvem com o feminismo, de acordo com os sujeitos que acreditam nesse tipo de afirmação - aqui, representando a voz de eleitores conservadores.

Assim, é possível inferir a característica dos memes de fazer referência a fatos reais, sobretudo a reportagens que abordem escândalos do governo ou declarações polêmicas. Em abril de 2019, a ministra da pasta Mulher, Família e Direitos Humanos, Damares Regina Alves, deu uma declaração ${ }^{6}$ de que a mulher, atenta aos princípios cristãos, deve ser submissa ao homem, visto que este é o chefe da família. Logo após a divulgação de sua fala, a página Barbie e Ken Cidadãos de Bem divulgou o seguinte meme:

6 Disponível em: https://g1.globo.com/politica/noticia/2019/04/16/damares-diz-que-em-suaconcepcao-crista-mulher-deve-ser-submissa-ao-homem-no-casamento.ghtml. Acesso em: 14 set. 2019. 
Figura 3. Barbie Submissa

\section{Sou submissa ao meu marido SIM Não tenho culpa se vocês escolheram o homem errado para amar e se casar}

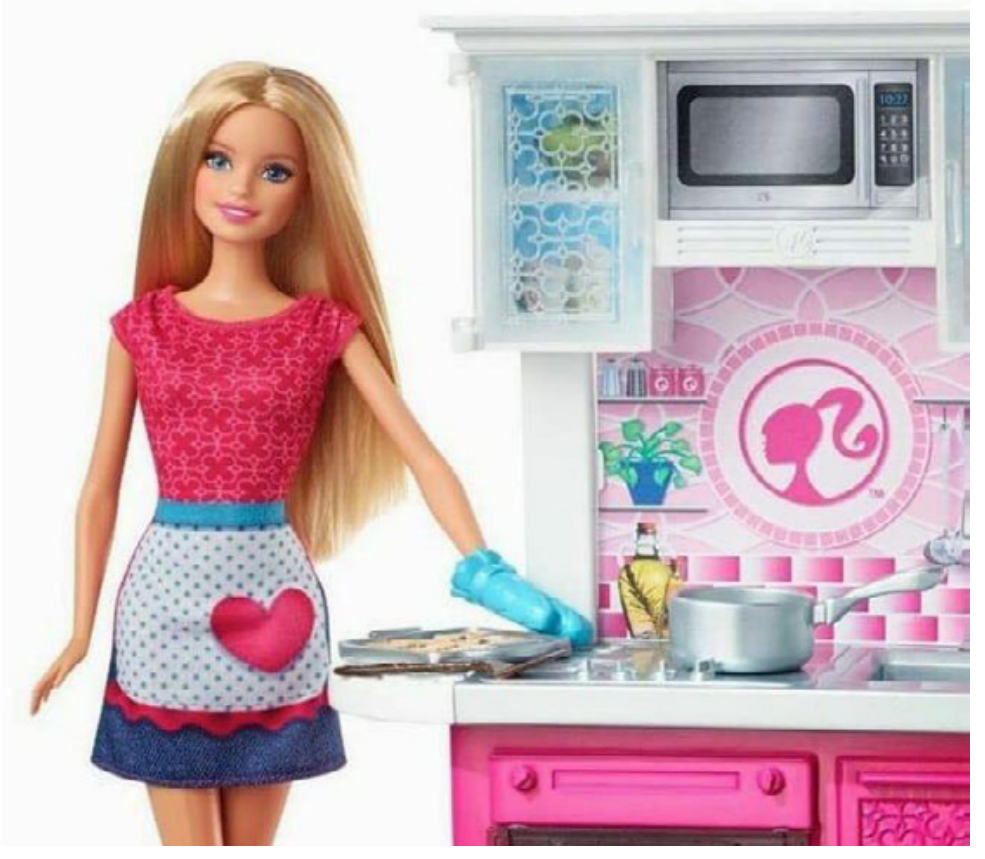

Fonte: Barbie e Ken Cidadãos de Bem, 2019, on-line (https://bit.ly/3h9Tq6X)

Em uma refração da realidade, o meme da figura 3 traz a boneca Barbie com um avental e uma luva térmica, em uma cozinha cor de rosa, preparando alimentos. A construção da figura, que remete a um ambiente específico da casa, a cozinha, reitera a ideia de que o lugar da mulher é o lar. O enunciado verbal dialoga com a declaração da ministra Damares de que a mulher deve ser submissa e, portanto, deve cozinhar para o marido e satisfazer suas vontades, além de não trabalhar fora do ambiente doméstico. Vemos no meme que a Barbie Fascista concorda com o posicionamento de Damares, sendo ambas defensoras da família, da moral e dos bons costumes. A ministra é conhecida por seus discursos considerados retrógrados, contrários à igualdade de gênero (segundo ela, "ideologia de gênero") e ao feminismo, que incentivam a delimitação de um "lugar de mulher". Quanto a esse atrelamento do espaço doméstico ao sexo feminino, Heleith Saffioti (1987, p. 11) postulou que 
Dada a desvalorização social do espaço doméstico, os poderosos têm interesse em instaurar a crença de que este papel sempre foi desempenhado por mulheres. Para a solidificação desta crença nada melhor do que retirar desta atribuição de papéis sua dimensão socio-cultural. Ao se afirmar que sempre e em todos os lugares as mulheres se ocuparam do espaço doméstico, eliminam-se as diferenciações históricas e ressaltam-se os característicos "naturais" destas funções.

Desse modo, podemos pensar que a mulher "bela, recatada e do lar", representada também pela figura da Barbie Fascista, é a síntese da "mulher ideal" para a sociedade patriarcal, conservadora e machista. Além disso, ela represente a "cidadã de bem", a mãe da família tradicional, atenta aos bons costumes, todos esses valores muito exaltados para o atual governo e recorrentes em governos autoritários ao redor do mundo.

Porém, sabemos que o discurso sempre está aberto para receber respostas, sejam essas em concordância ou discordância com o discurso do outro. Ainda com relação ao pronunciamento de Damares, um usuário do Facebook respondeu, em um comentário, o meme da figura 3. O comentário utilizou um meme (figura 4) com o enunciado verbal "A mulher deve servir o homem", e a imagem do quadro Salomé com a cabeça de São João Batista, do pintor italiano Guido Reni. Essa resposta ironiza o posicionamento de Damares, invertendo sua fala e modificando seu sentido ao alterar o complemento verbal - ao invés de servir ao homem, submeter-se, o novo enunciado sugere que a mulher sirva o homem, o que é corroborado com a imagem de Salomé segurando uma bandeja com a cabeça de João Batista.

Figura 4. A mulher deve servir o homem
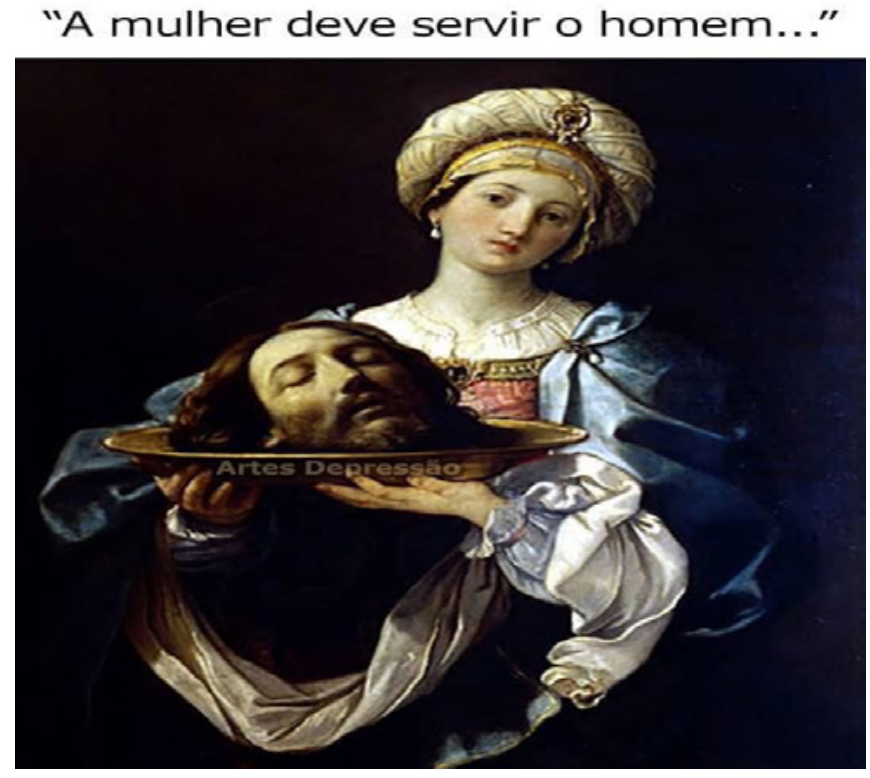

Fonte: Comentário no Facebook, 2019, on-line (https://bit.ly/2XKPIZC) 
Assim, com a alternância dos sujeitos na rede, que podem ter papéis múltiplos no Facebook (podem comentar, curtir, compartilhar publicações), vemos nesse meme como a interação entre os discursos possibilita uma multiplicidade de sentidos para um mesmo enunciado.

\begin{abstract}
A entonação que isola o discurso do outro (marcado por aspas no discurso escrito) é um fenômeno de tipo especial: é uma espécie de alternância dos sujeitos do discurso transferida para o interior do enunciado. Os limites criados por essa alternância são aí enfraquecidos e específicos: a expressão do falante penetra através desses limites e se dissemina no discurso do outro, que podemos transmitir em tons irônicos, indignados, simpáticos, reverentes (essa expressão é transmitida com o auxílio de uma entonação expressiva - no discurso escrito é como se a adivinhássemos e a sentíssemos graças ao contexto que emoldura o discurso do outro - ou pela situação extraverbal - ela sugere a expressão correspondente). (BAKHTIN, 2011, p. 299).
\end{abstract}

Por vezes, observamos nas páginas analisadas a associação da imagem de mulheres famosas, como atrizes e apresentadoras, com a figura da Barbie Fascista, em alusão a algum de seus posicionamentos considerados fúteis. Após a posse de Jair Bolsonaro, a página Barbie Fascista divulgou um enunciado meme referindo-se à nova primeira-dama, Michelle Bolsonaro. Durante a cerimônia, Michelle interpretou o discurso do marido para a Língua Brasileira de Sinais (LIBRAS).

Figura 5. Barbie em libras

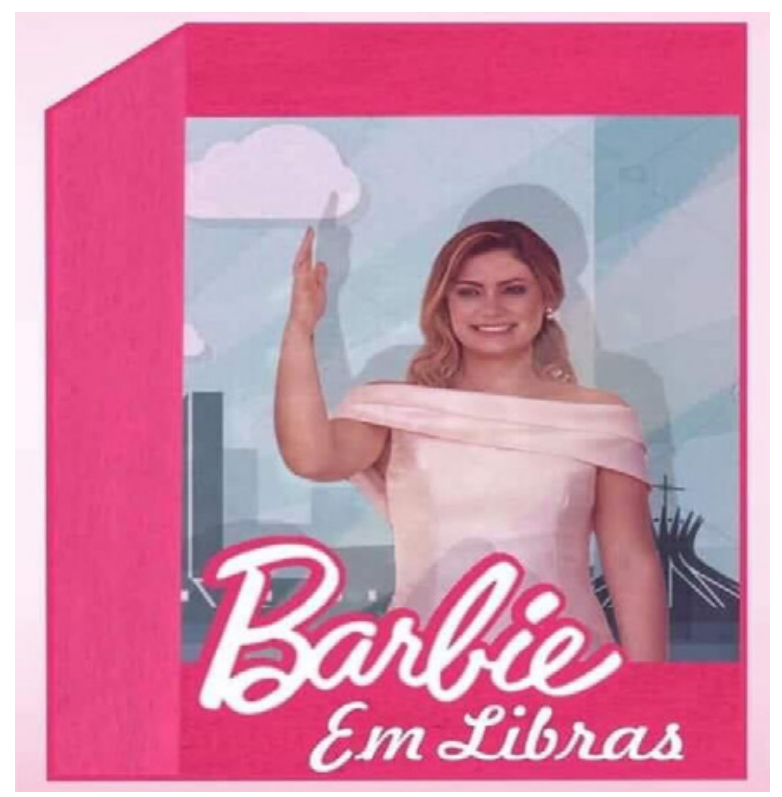

Fonte: Barbie Fascista, 2019, on-line (https://bit.ly/3hlxtC2) 
Vemos na figura 5 a proposta recorrente dos memes de fazer referência aos eventos políticos do país - ou seja, ao "contexto extraverbal" (BAKHTIN, sem data) que confere a plenitude de sentido do enunciado. A disposição da imagem remete à embalagem de uma boneca Barbie, com sua caixa rosa e com o visor espelhado que possibilita ver o brinquedo. O projeto de dizer dessa figura é estabelecer uma relação entre a Barbie (fascista) e Michelle, o que pode ser observado até mesmo pela foto escolhida, que mostra a primeira dama fazendo um gesto que se assemelha à posição imóvel de uma Barbie, com movimentos limitados. O vestido rosa, os cabelos loiros e o sorriso ajudam a compor o enunciado e a remeter à imagem da boneca e aos símbolos de feminilidade. Estampado na caixa, "Barbie em Libras" faz referência à participação da primeira-dama na posse e suas declarações sobre projetos sociais na igreja. Assim, compõe-se aqui uma crítica ao momento da posse, já que esse ato foi uma tentativa de inclusão feita por um governo que não contempla as minorias, além de enquadrar Michelle como uma Barbie devido a sua ligação com Bolsonaro e, consequentemente, com o conservadorismo, além de suas características físicas e sua posição de "esposa exemplar".

Assim como Marcela Temer, Michelle Bolsonaro também está dentro dos padrões de beleza, é casada com um representante político da direita e sempre aparece à sombra dele em suas aparições públicas e reforçando a ideia de família, um símbolo forte na campanha de Bolsonaro, além de retomar a máxima do senso comum de que "por trás de um grande homem há uma grande mulher". Tanto Marcela como Michelle são representadas sob o signo da Barbie, os internautas as representam como Barbies fascistas. Outras celebridades também enquadradas assim são Ana Hickmann e Marina Rui Barbosa, por conta de declarações que demonstram deslocamento social ou em apoio a Bolsonaro. Portanto, o padrão de mulher rica, branca e com posicionamentos de direita se repete e se instaura cada vez mais como uma alusão à Barbie e ao comportamento de um sujeito alienado, a uma mulher "bem Barbiezinha"..., porém, fascista.

\section{Considerações finais}

Intentamos evidenciar, com as exposições feitas neste trabalho, como os memes da Barbie Fascista se utilizam da ironia e do humor como uma forma de resistência ao governo Bolsonaro. Com enunciados memes que deslocam os discursos oficiais, as páginas analisadas convidam os usuários da rede social a tecerem críticas ao atual contexto político brasileiro, em uma interação que revela uma luta de classes sociais distintas.

Enquanto signo ideológico, a Barbie Fascista representa o projeto de dizer dos autores das páginas sobre a mulher de direita, rica, que não se importa com as disparidades sociais do país e só pensa em si mesma. Além disso, os memes são enunciados de forma a ridicularizar a fé cega dos eleitores de Bolsonaro, que o defendem apesar dos escândalos divulgados na mídia, geralmente valendo-se de argumentos volúveis e frágeis para debater com quem se opõe ao governo. 
Os memes, em diálogo direto com enunciados de outras esferas, exploram temas políticos, mas de forma suavizada. Ao provocarem o riso, esses enunciados denunciam pensamentos preconceituosos de cidadãos que se consideram e intitulam como "cidadãos de bem", evidenciam muitos dos estereótipos marcados na sociedade sobre as mulheres e como estas devem ser, que reiteram o cerceamento da liberdade feminina. Assim, é possível perceber que os memes constituem-se como uma maneira encontrada pelos usuários das redes sociais para resistir e se posicionar, em uma atualização do que anteriormente era feito por meio de tirinhas e charges.

A ironia que permite o riso nesses memes é a mesma que nos convida a refletir sobre o que é ser mulher na era Bolsonaro, indagar sobre quem é a mulher "cidadã de bem" e como ela é representada em enunciados de diversas esferas. Assim, entre embates de vozes sociais que colidem no discurso e na vida, temos um retrato do Brasil contemporâneo e, para além disso, uma construção de resistência. Em uma sociedade marcada pelo machismo, que insiste em classificar mulheres como belas, recatadas, submissas, "do lar", enfim, Barbies, quebrar os padrões é resistir e tomar a liberdade como substância.

\section{REFERÊNCIAS}

BAKHTIN, M. M. (VOLÓCHINOV). Discurso na vida, discurso na arte. Mimeo (traduzido para fins acadêmicos da versão inglesa), sem referência.

BAKHTIN, M. M. Teoria do romance II: as formas do tempo e do cronotopo. Rio de Janeiro: 34, 2018.

BAKHTIN, M. M. Teoria do romance l: a estilística. Rio de Janeiro: 34, 2015.

BAKHTIN, M. M. Questões de estilística no ensino da língua. Rio de Janeiro: 34, 2012.

BAKHTIN, M. M. Estética da Criação Verbal. São Paulo: Martins Fontes, 2011.

BAKHTIN, M. M. Cultura popular na Idade Média e no Renascimento - o contexto de François Rabelais. São Paulo: Hucitec, 2010.

BAKHTIN, M. M. Para uma filosofia do ato responsável. São Carlos: Pedro \& João, 2009.

BAKHTIN, M. M. Freudismo. São Paulo: Perspectiva, 2001.

BAKHTIN, M. M. Problemas da Poética de Dostoievski. São Paulo: Forense, 1997. 
BAKHTIN, M. M. Questões de Literatura e de Estética. São Paulo: UNESP, 1993.

BAKHTIN, M. M. Gêneros do discurso. São Paulo: 34, 2016.

BRAIT, B. Bakhtin: Conceitos-Chave. São Paulo: Contexto, 2005.

BRAIT, B. Ironia em perspectiva polifônica. Campinas: UNICAMP, 2008.

FARACO, C. A. Linguagem \& diálogo: as ideias linguísticas do Círculo de Bakhtin. São Paulo: Parábola, 2009.

MEDVIEDEV, P. N. Método formal nos estudos literários. São Paulo: Contexto, 2012.

SAFFIOTI, H. I. B. O poder do macho. São Paulo: Moderna, 1987. (Coleção polêmica)

VOLÓCHINOV, V. Marxismo e filosofia da linguagem: problemas fundamentais do método sociológico na ciência da linguagem. Rio de Janeiro: 34, 2017. 